\title{
ヒト病原細菌と細菌毒素に対する乳清タンパク濃縮物中の自然抗体
}

\author{
木島佳子，岩附 聡 ${ }^{\S}$ 赤松裕久*, 寺戸国昭**, \\ 桑原祥浩***, 上田成子 ${ }^{* * *}$, 塩野谷博 \\ アサマ化成株式会社 \\ * 静岡県畜産技術研究所 \\ ** Chondrex, Inc. \\ *** 女子栄養大学衛生学研究室
}

\section{Natural Antibodies to Pathogenic Bacteria and their Toxins in Whey Protein Concentrate}

\author{
Yoshiko Kijima, Satoshi Iwatsuki ${ }^{\S}$, Hirohisa Akamatsu*, Kuniaki Terato**, \\ Yoshihiro Kuwabara***, Shigeko Ueda*** and Hiroshi Shionoya \\ Asama Chemical Co., Ltd., 20-3 Nihonbashi Kodenma-cho, Chuo-ku, Tokyo 103-0001 \\ * Shizuoka Prefectural Institute of Animal Industry, 1945 Inokashira, Fujinomiya-shi, Shizuoka 418-0108 \\ ${ }^{* *}$ Chondrex, Inc., 2607 151st Place NE, Redmond, Washington 98052, USA \\ *** Laboratory of Hygiene, Kagawa Nutrition University, 3-9-21 Chiyoda, Sakado-shi, Saitama 350-0214
}

\begin{abstract}
Whey protein concentrate (WPC) is a byproduct of cheese and casein during the dairying process. It is currently used as a food additive or nutritional supplement. To determine a more beneficial use of WPC, we focused on the antibodies against potential pathogenic bacteria and their toxins contained in WPC. The immunoglobulin content of WPC products varied from 0 to $5.2 \%$. Antibody specificity was analyzed for 33 species of heat-killed pathogenic bacteria and 5 types of bacterial toxins. Specific antibodies to the respective antigens were found, suggesting that antibodies to other bacteria and toxins that were not used in this study might also exist in WPC. Moreover, absorption experiments showed that WPC contained cross-reactive antibodies to other bacteria. Based on these findings, whey antibodies may possess a potential therapeutic usage for treatment of patients with autoimmune diseases such as rheumatoid arthritis, in which bacterial toxins and an abnormal balance of intestinal bacterial flora are major fundamental factors.
\end{abstract}

(Received Sep. 29, 2008 ; Accepted Jun. 4, 2009)

Keywords : anti-bacterial antibody, bacterial toxin, immunoglobulin, pathogenic bacterial flora, bacterial toxin, whey protein concentrate

キーワード : 乳清タンパク, 抗菌抗体, 抗毒素抗体

ウシの初乳には抗体が豊富に含まれており，これにより 免疫機能の未完成である新生ウシは微生物感染を免れて成 長する. 妊娠ウシにヒトの病原微生物をワクチン接種して 得られる免疫初乳から調製した免疫ミルク抗体製品は, ヒ トにおける細菌感染, ウイルス感染による下痢などの治療 に有効であるとする報告は多く，総説となっている ${ }^{1)}$. 一 方, 妊娠ウシに免疫しなくと屯, ウシ初乳の抗体画分屯新 生児の抗生物質使用による菌交代症性下瘌 $\left.{ }^{2}\right)$ や， エイズ患

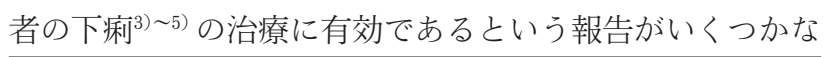

干103-0001 東京都中央区日本橋小伝馬町 20-3

* $\mathbf{T} 418-0108$ 静岡県富士宮市猪之頭 1945

** 2607 151st Place NE Redmond, Washington 98052 USA

*** \%350-0214 埼玉県坂戸市千代田 3-9-21

\&連絡先 (Corresponding author), iwatsuki@asama-chemical.co.jp
されている。これらの報告は, ウシの抗体の摂取はヒトの 消化管において病原菌を除去する機能を有することを示 し, 免疫をしていないウシ初乳抗体でも同様の機能が期待 できるあのと理解されている.

このように，ウシのいわゆる自然抗体がヒトにおいて奏 効するのは, ヒトとウシに共通して感染する病原微生物 (大腸菌, サルモネラ, カンピロバクター, レンサ球菌な (゙6) 8) ) が存在すること, また抗原性が共通するノロウイ ルス, ロタウイルスなど9) 11) の感染により産生される抗体 があることによると考えられる.

また, 病原微生物はエンドトキシンやエンテロトキシン, その他の毒素を産生するため, 毒素に対する抗体屯ウシの 自然抗体に含まれると考えられる。実際, Bölke は胃癌開 
腹手術に伴う血中エンドトキシン濃度の上昇がウシ初乳抗 体製品の摂取により抑制できることを報告している ${ }^{12)}$.

ヒトの腸内には共生関係にある細菌と, 無害・有害細菌 など 100 兆個の細菌が常在して腸内細菌叢を形成し, 健 康・栄養に密接に関わっている. 腸内細菌叢は加齢ととも に変化し, 有害細菌が増加することを光岡らが明らかにし ている ${ }^{13)}$. 腸内細菌叢の悪変の要因として, 加齢に伴う腸 管免疫の低下が重要と考えられる.

腸内細菌やそれらが産生する細菌毒素は，消化管壁バリ アーを通過して体内へ移行する. これをトランスロケー ション14)という。 トランスロケーションは, 外傷, 火傷, 手術などに伴うストレスはもとより，精神的ストレス ${ }^{15)}$, 制癌剂 ${ }^{16)}$ や酸性消炎鎮痛剤 ${ }^{17)}$ などの薬剤によっても克進 することが知られている. 細菌毒素は免疫系細胞を非特異 的に活性化させ, 腫瘍壊死因子 ( TNF) などの炎症性サイ トカイン産生を促すことから，ストレスや疾患による体調 不良や自己免疫疾患の発症に関係すると考えられる.

ウシの抗体の摂取により, 加齢による免疫低下の抑制, 腸内細菌叢の加齢による变化の抑制, 腸内の細菌毒素の中 和が可能であれば, ヒトの体調改善や健康維持, 自己免疫 病などの改善効果が期待できる.

ウシが生乳に分泌する抗体は, 人乳では IgA が主であ るのに対して, IgG1 が $90 \%$ を占める ${ }^{18)}$. 生乳中の抗体は, チーズ製造の残留液であるチーズホエー, またはカゼイン 製造で残る酸ホエー中に回収でき, 製造条件によってはホ エーのタンパク画分である乳清タンパク濃縮物（以下, WPC と略す）に濃縮され, 抗体含有量の高い WPC が得 られる. 現在, 日本に輸入されているWPC は年間およそ $10000 \mathrm{t}$ ある. しかし, その大部分は食肉加工, 製菓・製パ ンなど, 加熱加工食品に広く使われており, ウシの抗体は 失活している。我々は，WPC 中に含まれる抗体を貴重な 機能性食品素材として捉え, 抗体の本質を活かした有効利 用に関心を持った。 そこで, 先ず WPC 中の抗体 (IgG) の 量と共に, その特異性についての情報を得るため, 抗体の 測定方法を開発してその評価を行った.

\section{実 験 方 法}

\section{1. 乳清タンパク濃縮物 (WPC)}

WPC はアメリカ, オセアニア, ヨーロッパ産の 15 品, いずれも初乳不含品を入手した。

\section{2. 試 薬}

Escherichia coli O26, O55, O111 由来 TCA 抽出リポ多 糖 (LPS), ブドウ球菌エンテロトキシン B (SEB), Salmonella minnesota R595 由来 Diphosphoryl lipidA (lipid A）はそれぞれ Sigma 社より購入した。

\section{3. 細 菌}

Bacteroides flagilis JCM11019 は理研 BRC より, Helicobacterpylori ATCC43504 は ATCCより, Escherichia coli
O111 : B4 および Salmonella minnesota R595 は東京大学 医科学研究所より入手した. Staphylococcus epidermidis, Streptococcus pyogenes Type 1, Streptococcus pyogenes Type 12, Streptococcus pyogenes Type 22, Streptococcus mitis, Streptococcus sanguis, Streptococcus salivarius, Streptococcus mutans, Streptococcus pneumoniae, Salmonella enteritidis, Shigella dysenteriae, Aerobacter aerogenes, Propionibacter acnes, Haemophilus influenzae, Klebsiella pneumoniae, Campylobacter jejuni, Bacillus cereus, Listeria monocytogenes, Yersinia enterocolitica, Pseudomonas aeruginosa, Candida albicans, Proteus vulgaris, Salmonella typhimurium, Serratia marcescens, Escherichia coli O157 : H7 は女子栄養大学保存株である. Alcarigenes faecalis IFO13111, Enterobacter cloacae JCM 1232, Clostridium perfringens, Staphylococcus aureus IFO $12732 （ \mathrm{p})$ はアサマ化成保存株を用いた。

\section{4. 細菌の培養}

E. coli O111, A. faecalis, S. aureus, E. cloacae はパー ルコア標準寒天培地 (栄研) を用いて培養した. H. pylori は 5\%ウマ血清添加 TSA 培地 (BBL 11043), C. jejuni は ブレインハートインフュージョン (BHI) 寒天培地で, ア ネロパック (三菱ガス(株)）を用いて微好気培養した。C. albicans はサブロー培地を, 他の女子栄養大保存株は BHI 寒天培地を用いて培養した. 全ての菌は, 寒天平板に塗沫 し培養した。

\section{5. 菌体抗原の調製}

加熱処理菌体は，培養平板に冷却したリン酸緩衝生理食 塩水 (pH 7.3, 以下 PBS とする) を加えて回収し, 沸騰水 浴中で 60 分加熱した.

ホルマリン処理菌体は, 培養平板に $5 \%$ ホルマリン加 PBS を加えて回収した。

各菌体は PBS で 3 回遠心洗浄後, 懸濁液の $660 \mathrm{~nm}$ にお ける吸光度が 10 (OD10) となるようにPBS で調製し，アジ 化ナトリウムを $0.1 \%(\mathrm{w} / \mathrm{v})$ 濃度に加え, 冷蔵保存した。

\section{6. 精製抗 $E$. coli 0111 LPS 抗体の調製}

抗細菌, および抗細菌毒素抗体の定量的測定のための標 準品として，E. coli O111：B4 加熱菌を油性アジュバント処 理して妊娠ウシに免疫し, その初乳より LPS アフィニティ カラム ${ }^{19)}$ とプロテイン G カラム (HiTrap ProteinG HP, Amersham Bioscience, Sweden）を用いて抗 E. coli O111 LPS 抗体を精製した.この操作を 3 回繰り返した. ELISA ではそれ以上の精製後に比活性の上昇は見られなかった。 この標品はアクリルアミドディスク電気泳動で単バンドで あった。

\section{7. 抗ニワトリ I 型コラーゲン抗体の調製}

ニワトリா型コラーゲン (Chondrex, USA) を妊娠ウシ に免疫した. 免疫牛初乳より，ニワトリ型コラーゲンカ ラムとプロテイン Gカラムを用いて抗ニワトリII型コ 
ラーゲン抗体を精製した。

\section{WPC 溶液の調製}

WPC 粉末を正確に秤量し, PBS で $10 \%$ 濃度に溶解し, その $16000 \mathrm{rpm}, 30$ 分遠心上清を希釈して用いた。

\section{9. ウシ IgG の定量}

(1) 一元免疫拡散法 (SRID) による総 IgG 含有量の測定

The Binding Site 社 (Birmingham, U.K.) の Bovine IgG- NL RID を用いた。

(2) Enzyme Linked Microbial cell Binding Antibody Assay（ELMBA）による抗細菌抗体の定量

$\mathrm{WPC}$ 溶液サンプルおよび検量線作成に用いた精製抗 $E$. coli O111 LPS 抗体は PBS で希釈した. マイクロチューブ にWPC 溶液 $1 \mathrm{ml}$ と OD10 の菌液 $100 \mu 1$ を混合し, 振と うしながら $4{ }^{\circ} \mathrm{C}$ で一晚反応させた。菌体を PBS で 3 回遠 心洗浄した。沈澱に第二抗体として $1 \%$ ウシ血清アルブミ ン， 0.05\% Tween20，3\% 塩化ナトリウムを含むPBS で 200 倍に希釈したペルオキシダーゼ標識抗ウシ IgGウサギ

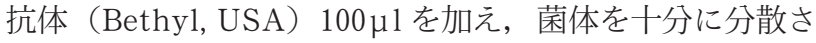
せた後，振とうしながら $4{ }^{\circ} \mathrm{C}$ で一晚反応させた。 反応後, PBS にて 5 回遠心洗浄し, 得られる沈澱にPBS $200 \mu 1$ を 加え分散させた。この $10 \mu 1$ を試験管に取り, 発色試薬と してオルトフェニレンジアミン（OPD）溶液を $2 \mathrm{ml}$ 加え て $37^{\circ} \mathrm{C}$ で 30 分反応させた後, $3 \mathrm{~mol} / 1$ 塩酸を $500 \mu \mathrm{l}$ 加え て反応を停止し，分光光度計にて $490 \mathrm{~nm}$ に打ける吸光度 を測定した。

抗体の検量線は精製抗 E. coli O111 LPS 抗体の 10～40 $\mathrm{ng} / \mathrm{ml}$ を含む溶液とE. coli O111：B4 の加熱菌体を用いて 作成した. 全ての測定で 2 本の試験管の吸光度から，抗 $E$. coli O111 LPS 抗体換算值として抗体量を求めた.この測 定方法を Enzyme Linked Microbial cell Binding Antibody Assay(ELMBA) と称する.

(3) ELISA による抗細菌毒素 (LPS, SEB, lipid A) 抗体 の測定

LPS, SEB はそれぞれ $0.1 \mathrm{~mol} / 1$ 炭酸緩衝液 $(\mathrm{pH}$ 9.5) で, lipid A はクロロホルム・メ夕ノール 4: 1 混合液に溶解後, メタノールで希釈した後, ELISA プレート(Nunc439454) に加え抗原をコートした．抗原なしのウェルには炭酸緩衝 液またはメ夕ノールを添加した。トリス，塩化ナトリウム を含むヤギ血清でブロックを行い，次に検量線作成のため の精製抗 E. coli O111 LPS 抗体，検体とした WPC 溶液を ブロック液で希釈し，ウェルに加え反応させた。第二抗体 にはビオチン標識抗ウシ IgG ヤギ抗体 (Jackson ImmunoResearch）を使用した。次にExtrAvidin-Peroxidase （SIGMA）を反応させ，3，3'，5,5'-Tetramethylbenzidine 溶液を添加し室温で 10 分反応させた後, $3 \%(\mathrm{v} / \mathrm{v})$ 塩酸で 反応を停止し，マイクロプレートリーダー（Bio Rad, Model 550)で $450 \mathrm{~nm}$ における吸光度を測定した。抗体量は Microplate Manager III（Bio-Rad）により計測した。抗原コー
トウェルと抗原をコートしないウェルにおける計測值の差 をその検体濃度における抗体の濃度とした。抗体含有量は 検体希釈倍数を乗じて WPC1g 中の含有量として表した.

\section{WPC 抗体の菌体による吸収試験}

WPC 溶液の菌体による吸収試験に際し, 抗体と菌との 非特異的な反応による抗体の減少の程度を知る指標とし て, 細菌と反応性がない抗二ワトリ I型コラーゲン抗体 (以 下，抗コラーゲン抗体とする）をWPC 溶液に添加して実 験した。抗コラーゲン抗体添加 WPC1\% PBS 溶液 $1.5 \mathrm{ml}$ にホルマリン処理菌体の $10000 \mathrm{~g}$ 遠心ペレット $1.5 \mathrm{ml}$ 加え, $4^{\circ} \mathrm{C}$ にて一晚振とうの後, $10000 \mathrm{~g}$ 遠心上清を採取し た。これに再度菌の遠心ペレット $1.5 \mathrm{ml}$ を加え， $4^{\circ} \mathrm{C}$ にて 一晚振とうし，遠心上清を調製した。対照として，菌の遠 心ペレットの代わりにPBS $1.5 \mathrm{ml}$ を用いた。

細菌菌体之 $1 \% \mathrm{WPC}$ に含まれる抗体の接触により，非特 異的反応による抗体の除去が考えられる。 また, 対照 WPC に加えた PBS により, 対照 WPC の液量は吸収 WPC の液 量よりも多く希釈される. 吸収 WPC において, 吸収菌体 添加による抗体の非特異的吸着と対照 WPC における液量 の増加を補正するために，1\% WPC 液には菌体との交差 抗原性を有さない抗コラーゲン抗体を添加し, 吸収操作に おける非特異的吸着による抗体量の減少を補正した。

菌に対する抗体はELMBAにより，抗コラーゲン抗体 はELISAにより測定した。

対照 WPC は, WPC 溶液 $1.5 \mathrm{ml}$ に対し, 吸収菌体ペレッ 卜 $1.5 \mathrm{ml}$ の変わりに, PBS $1.5 \mathrm{ml}$ を 2 回, 計 $3 \mathrm{ml}$ 加えら れているために，吸収 WPC におけるよりあより多く希釈 されている. 従って, 抗コラーゲン抗体濃度が 2 回の菌体 による吸収操作により，E. coli O-111 菌体では 85.9\%, S. minnesota 菌体では $71.8 \%$ に減少した吸収では, 吸収群に 比べて対照における液量の増加のみとして，2 回の吸収菌 体ペレット計 $3 \mathrm{ml}$ は, 菌体外液量のそれぞれ, $2.4 \mathrm{ml}, 1.7$ $\mathrm{ml}$ に相当する. また, 従って, 菌体ペレットの水を除いた 菌体容積は E. coli O-111 菌体では $0.6 \mathrm{ml}$, S. minnesota 菌 体では $1.3 \mathrm{ml}$ となった。

以上のことから，この吸収試験における WPC 抗体溶液 の容積変化と非特異吸収を補正できると判断した。

\section{実験結果および考察}

\section{1. 総 IgG 含有量}

SRID により測定した 15 の WPC 製品中のウシ IgG 含 有量は $2 \%$ 以下が 7 製品，2 3\% が 3 製品，4\%台が 3 製 品， $5 \%$ を超えるものが 2 製品であった。生乳の IgG 含有 量を $0.5 \mathrm{mg} / \mathrm{ml}^{18)}$ として, 全ての $\mathrm{IgG}$ が WPC 中に移行し た場合，WPCの IgG 含有量は約 $8 \%$ となる。ウシ IgGは 熱変性を受けやすく, 加熱による影響を受けない温度は $60^{\circ} \mathrm{C}$ であると報告されている ${ }^{20)}$. WPC 製品は，その製造 工程において噴霧乾燥の工程を経る。WPC 15 製品のうち 
$5 \%$ を超える IgG 含量の製品はわずかに 2 製品であったこ とは，WPCの製造過程で多くの製品において加熱変性に よる抗体の損失のあることが示唆された.

\section{2. 抗細菌抗体含量}

菌体に対する抗体含有量の評価に当たって, 通常酵素免 疫測定法 (ELISA) が行われることが多い.しかし, 夾雑す る抗体が多い場合, ELISA では抗原特異的な抗体量の正 確な評価が困難である。これは ELISA プレートに非特異 的に結合する抗体を阻止することができないことによると 考えられる. ELISA による抗体の測定は通常, 抗原をコー トしていないウェルにおける吸光度がほぼ 0.1 以下になる ように検体を希釈して行われる。しかし, 測定の対象とす る抗体量が十分でない場合は, 検体の希釈により特異的抗 体による発色む失われるために定量することができない. この問題を避けるためには, 測定対象とする抗体以外の夾 雑する抗体が除かれることが必要である.

細菌菌体は遠心操作により沈澱するので, 菌体に結合し た抗体と, 夾雑する抗体を容易に遠心洗浄により分けるこ とができる，そこで本研究では，ELISA プレートを用い ず，非特異抗体を遠心洗浄により除去し，次にペルオキシ ダーゼ標識第二抗体と反応させ, 発色させる方法を確立し, 測定した。

抗体検出感度をホルマリン処理菌体と加熱処理菌体とで

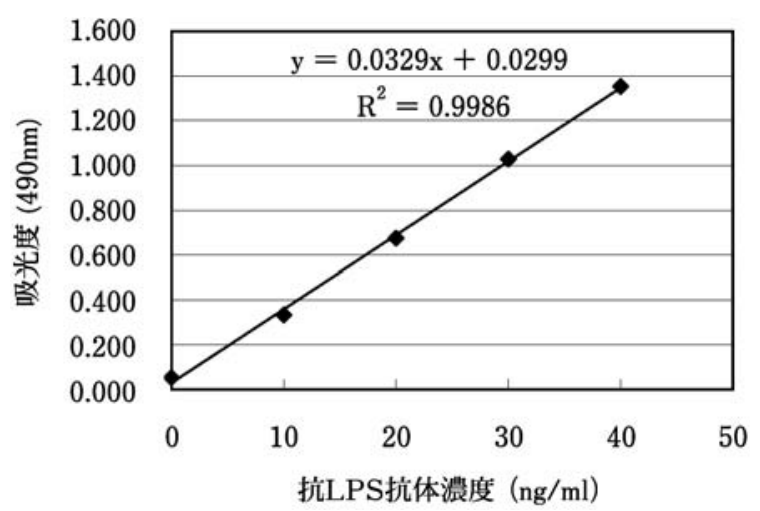

図 1 抗細菌抗体測定の検量線の一例
比較すると，加熱処理菌体が良好であった。 また，S. epidermidis, S. pyogenes Type 1, S. pyogenes Type 22 の加 熱処理菌体は, それ自体がペルオキシダーゼ標識抗ウシ IgG ウサギ抗体と結合し，プロテイン A やプロテイン G などの抗体結合タンパクが存在するあのと考えられた。こ れらのタンパクを菌体成分として持つ細菌については，こ れを失活させる必要があり, $121^{\circ} \mathrm{C}, 15$ 分オートクレーブ 処理をした。

抗体量は精製抗 E. coli O111 LPS 抗体を標準品として検 量線を作成して求めた。検量線は測定の都度作成し, 困 1 にその一例を示した。 また，ELMBAにおける測定值の再 現性については，同一菌体を用いて抗細菌抗体量を測定し た結果を表 1 に示した。測定ロットにより程度は異なる が，再現性は良好であると考えられた。

生産地の異なる 2 つの WPC 製品（WPC-1, WPC-6）に ついて, 主としてヒト由来病原菌 33 種に対する抗体量の 測定結果を表 2 に示した。 2 製品を比較し，抗体含量の高 い方を太字で示した. WPC-1, WPC-6 共にC. jejuni に対 する抗体は WPC $1 \mathrm{~g}$ 中 $5 \mathrm{mg}$ 以上含まれ, WPC-6 では $H$. pylori に対し $5 \mathrm{mg}$ 以上, S. mutans に対しては $2 \mathrm{mg}$ 以上 の抗体が含まれていた。

この 2 つ製品の SRID で測定した総 IgG 含有量は WPC-1 が 52 mg/g, WPC-6 が 29.0 mg であった. 2 製品に ついて比較すると, WPC-6 は WPC-1 に比べて, 総 IgG 含 有量は 0.56 倍であるにも関わらず, 抗細菌抗体量の総和は 2 倍弱であり, 総 IgGに占める抗細菌抗体の割合が高かっ た.すなわち, 総 IgG 含有量は必ずしもヒト病原菌に対す る抗体量を反映しない場合があることが示された。このこ とから，ウシ抗体の䝮取によりヒト腸内細菌叢などへの影 響を意図してWPC を用いる場合には, 総 IgG 含有量のみ の測定では不十分であると考えられた。

\section{3. 抗体の菌体による吸収試験}

表 2 に示されたのヒト由来病原菌に対する抗体量は SRID による総 IgG 含有量はとは相関しないことを示され た。 また, WPC-6 では総 IgG 含有量 $29 \mathrm{mg} / \mathrm{g}$ に対して, 抗細菌抗体量の総和は $17.3 \mathrm{mg}$ であった。僅か 33 の細菌

表 1 ELMBA における抗細菌抗体測定值の再現性

\begin{tabular}{|c|c|c|c|c|}
\hline 菌名 & 実験 & $\begin{array}{c}\text { WPC 溶液の抗体濃度 } \\
(\mathrm{ng} / \mathrm{ml})\end{array}$ & $\begin{array}{c}\text { 測定時 WPC 濃度 } \\
(\mu \mathrm{g} / \mathrm{ml})\end{array}$ & $\begin{array}{c}\text { 抗体含有量 } \\
(\mu \mathrm{g} / \mathrm{g} \text { WPC })\end{array}$ \\
\hline \multirow{2}{*}{ Escherichia coli O111 : B4 } & 実験 1 & 21.7 & 50 & 434 \\
\hline & 実験 3 & 22.6 & 50 & 452 \\
\hline \multirow{2}{*}{ Salmonella minnesota R595 } & 実験 2 & 7.2 & 200 & 36.0 \\
\hline & 実験 3 & 11.4 & 500 & 22.8 \\
\hline \multirow{2}{*}{ Bacillus cereus } & 実験 1 & 74.6 & 200 & 373 \\
\hline & 実験 3 & 41.8 & 100 & 418 \\
\hline \multirow{2}{*}{ Clostridium perfringens } & 実験 1 & 29.7 & 100 & 297 \\
\hline & 実験 3 & 34.3 & 100 & 343 \\
\hline
\end{tabular}


表 2 WPC 中のヒト由来病原菌に対する抗体

\begin{tabular}{|c|c|c|c|c|}
\hline \multirow{2}{*}{ 細菌名 } & \multicolumn{2}{|c|}{ WPC-1 } & \multicolumn{2}{|c|}{ WPC-6 } \\
\hline & $\mu \mathrm{g} / \mathrm{g}^{*}$ & 抗体\% & $\mu \mathrm{g} / \mathrm{g}^{*}$ & 抗体\% \\
\hline Aerobacter aerogenes & 16.2 & 0.03 & 47.5 & 0.16 \\
\hline Alcaligenes faecalis IF013111 & 142.0 & 0.27 & 277.0 & 0.96 \\
\hline Bacillus cereus & 34.6 & 0.07 & 125.0 & 0.43 \\
\hline Bacteroides fragilis JCM11019 & 172.0 & 0.33 & 262.0 & 0.90 \\
\hline Campylobacter jejuni & 5000.0 & 9.62 & 5000.0 & 17.24 \\
\hline Candida albicans & 67.5 & 0.13 & 26.2 & 0.09 \\
\hline Clostridium perfringens & 212.0 & 0.41 & 282.0 & 0.97 \\
\hline Enterobacter cloacae JCM1232 & 163.0 & 0.31 & 328.0 & 1.13 \\
\hline Escherichia coli O111 : B4 & 184.0 & 0.35 & 374.0 & 1.29 \\
\hline Escherichia coli $\mathrm{O} 157$ : H7 & 57.0 & 0.11 & 203.0 & 0.70 \\
\hline Haemophilus influenzae & 214.0 & 0.41 & 165.0 & 0.57 \\
\hline Helicobacter pylori A TCC43504 & 1915.0 & 3.68 & 5000.0 & 17.24 \\
\hline Klebsiella pneumoniae & 9.3 & 0.02 & 54.5 & 0.19 \\
\hline Listeria monocytogenes & 86.6 & 0.17 & 53.4 & 0.18 \\
\hline Propionibacter acnes & 64.5 & 0.12 & 154.0 & 0.53 \\
\hline Proteus vulgaris & 87.6 & 0.17 & 136.0 & 0.47 \\
\hline Pseudomonas aeruginosa & 84.5 & 0.16 & 121.0 & 0.42 \\
\hline Salmonella enteritidis & 19.8 & 0.04 & 45.7 & 0.16 \\
\hline Salmonella minnesota R595 & 28.4 & 0.05 & 18.4 & 0.06 \\
\hline Salmonella typhimurium & 28.1 & 0.05 & 52.0 & 0.18 \\
\hline Serratia marcescens & 47.7 & 0.09 & 55.0 & 0.19 \\
\hline Shigella dysenteriae & 37.2 & 0.07 & 280.0 & 0.97 \\
\hline Staphylococcus aureus IFO12732 (p) & 27.9 & 0.05 & 7.4 & 0.03 \\
\hline Staphylococcus epidermidis & 27.3 & 0.05 & 55.0 & 0.19 \\
\hline Streptococcus mitis & 29.4 & 0.06 & 84.4 & 0.29 \\
\hline Streptococcus mutans & 13.6 & 0.03 & 2280.0 & 7.86 \\
\hline Streptococcus pneumoniae & 17.6 & 0.03 & 172.0 & 0.59 \\
\hline Streptococcus pyogenes T1 & 131.0 & 0.25 & 260.0 & 0.90 \\
\hline Streptococcus pyogenes T12 & 73.6 & 0.14 & 393.0 & 1.36 \\
\hline Streptococcus pyogenes T22 & 78.5 & 0.15 & 344.0 & 1.19 \\
\hline Streptococcus salivarius & 31.6 & 0.06 & 296.0 & 1.02 \\
\hline Streptococcus sanguis & 12.8 & 0.02 & 234.0 & 0.81 \\
\hline Yersinia enterocolitica & 59.0 & 0.11 & 145.0 & 0.50 \\
\hline 計 & 9173.3 & 17.64 & 17330.5 & 59.76 \\
\hline 平均 & 278.0 & 0.53 & 525.2 & 1.81 \\
\hline 総 IgG 含有量 / g** $^{* *}$ & $52 \mathrm{mg}$ & & $29 \mathrm{mg}$ & \\
\hline
\end{tabular}

* : ELMBA による測定

** : 一元免疫拡散法 (SRID) による測定值

に対する抗体量の総和が，総 IgG 量の $20 \sim 50 \%$ 以上を占 めるということは, 菌別の抗体測定では多種の細菌に共通 して結合し得る抗体，すなわち交差反応する抗体の存在が 示唆された。 そこで，WPC-6 中抗体の菌体（E. coli O111 およびS. minnesota）による吸収試験を試みた。

その結果を表 3 に示した。表中，抗コラーゲン抗体量は 吸収抗原とした E. coli O111 おおびS. minnesota の菌体に よる吸収操作による抗体濃度の減少を示す。従って, 吸収 による抗体の減少は，非特異的な減少を補正した補正残存 率が $90 \%$ 以下となった細菌を交差抗原を有するものと判

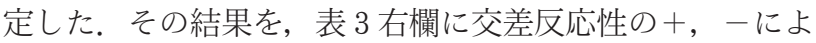

り示した. すなわち, E. coli O111での吸収により WPC に 含まれる抗 E. coli O111 抗体は P. aeruginosa ともほぼ同 程度に反応した。 また，S. minnesota での吸収により，E. coli O111 のみならず，グラム陽性菌の B. cereus と屯反応 する抗体が含まれていた。 すなわち，WPCには細菌に対 して広範に反応し得る抗体が含まれることが示された。

\section{4. 抗細菌毒素抗体量}

WPC-1，WPC-6 の細菌毒素に対する抗体を LPS（E. coli O26， 55，111 株由来)，SEB， lipid A について ELISA によ り測定した結果を表 4 に示した. LPS, lipid A に対する抗 体は 2 製品とも同様の含有量であった. SEB に対する抗体 
表 3 WPC 抗体の細菌菌体による吸収試験

\begin{tabular}{|c|c|c|c|c|c|c|}
\hline 吸収抗原 & 抗体測定抗原 & $\begin{array}{c}\text { 吸収 WPC } \\
n g / m l\end{array}$ & $\begin{array}{c}\text { 対照 WPC } \\
n g / m l\end{array}$ & $\begin{array}{c}\text { 残存率 } \\
\%\end{array}$ & $\begin{array}{c}\text { 補正残存率 } \\
\%\end{array}$ & 交差反応 \\
\hline \multirow{5}{*}{ E. coli $\mathrm{O} 111$} & E. coli $\mathrm{O} 111$ & 82.7 & 218.8 & 37.8 & 44.0 & + \\
\hline & P. aeruginosa & 27.4 & 70.2 & 39.1 & 45.5 & + \\
\hline & B. cereus & 666.7 & 854.6 & 78.0 & 90.8 & - \\
\hline & C. perfringens & 404.3 & 405.6 & 99.6 & 115.9 & - \\
\hline & Type II collagen & 1700 & 1980 & 85.9 & 100.0 & - \\
\hline \multirow{6}{*}{ S. minnesota } & E. coli $\mathrm{O} 111$ & 130.6 & 589.3 & 22.2 & 30.9 & + \\
\hline & S. minnesota & 15 & 43.1 & 34.9 & 48.6 & + \\
\hline & $P$. aeruginosa & 38 & 38 & 100.0 & 139.3 & - \\
\hline & B. cereus & 355.5 & 759.9 & 46.8 & 65.2 & + \\
\hline & C. perfringens & 131.4 & 171.7 & 76.5 & 106.5 & - \\
\hline & Type II collagen & 1550 & 2160 & 71.8 & 100.0 & - \\
\hline
\end{tabular}

抗菌抗体はELMBA により, 抗コラーゲン抗体は ELISA により測定した。

Type II collagen 抗体は菌体添加による吸収操作の過程で, 抗体の非特異的吸着と液量变化による抗体濃 度を補正するために実験系に添加した。詳しくは実験方法を参照されたい。

表 4 WPC2 製品の細菌毒素に対する抗体

\begin{tabular}{cccc}
\hline \hline \multirow{2}{*}{\begin{tabular}{c} 
細菌毒素 \\
\cline { 2 - 3 }
\end{tabular}} & \multicolumn{2}{c}{ 抗体含量 $\mu \mathrm{g} / \mathrm{g}$} & WPC \\
\cline { 2 - 4 } エンドトキシン & E. coli $\mathrm{O} 26$ & WPC-6 \\
\hline エンドトキシン & E. coli $\mathrm{O} 55$ & 11.77 & 13.80 \\
エンドトキシン & E. coli $\mathrm{O} 111$ & 4.60 & 4.30 \\
lipid A & & 2.27 & 1.80 \\
ブドゥ球菌エンテロトキシン B & 2.38 & 0.85 \\
\hline
\end{tabular}

はWPC-1の $2.38 \mu \mathrm{g} / \mathrm{g}$ に対し, WPC-6 は $1.18 \mu \mathrm{g} / \mathrm{g}$ で, WPC-1 において含有量が高い傾向がみられたが，S. aureus 菌体に対する抗体も WPC-1 で高い值を示したことと一致 していた.

\section{結 言}

本研究では, 細菌毒素に対する抗体の検索を重視する観 点から，抗エンドトキシン抗体，抗ブドウ球菌エンテロト キシン抗体とともに, lipid A に対する抗体の測定も行った.

免疫学的には, lipid A は多くのグラム陰性菌の交差抗 原である ${ }^{2122)}$. 腸内細菌細胞壁の交差抗原については, lipid A 部分の他, LPSのコアー部分 ${ }^{2223)}$, CEA 等があ $ろ^{24)}$. さらに, グラム陰性菌とグラム陽性菌の交差抗原と しては，ムコペプチドがある25). 今回の吸収試験の結果に これらの交差抗原に対する抗体がどの程度関与しているか は不明であるが, 総 IgG 量と抗細菌抗体量の総和の比率か ら想定すると，交差抗原に対する抗体は，WPCに含まれ る抗体において高い割合を占めていると考えられる.

本研究に用いた WPC の抗体は非免疫ウシの自然抗体で ある. 表 2 に示したように, 免疫しなくとも, C. jejuni, H. pylori, S. mutans に高い抗体価を示した. 33 種の細菌と細 菌毒素は任意に選択したあのであり, これら全ての細菌と
毒素に対する抗体が検出されたことは，未測定の細菌や毒 素, ウイルスに対する抗体む WPC 中に含まれることを示 唆している.このことは, また, ウシ抗体の利用に当たっ て必ずしもウシにワクチン接種しなくとも, WPC に十分量 の抗体を濃縮できることを示している.

ただし，当然のことではあるが，これらの濃縮された抗 体力価がヒトの健康増進に役立つか否かについては, 臨床 評価に待たねばならない。

加齢や各種ストレスにより免疫機能は低下する ${ }^{26) ~ 30) . ~}$ しかし，加齢動物に免疫増強刺激を与えても反応しないこ とが報告されている ${ }^{31)}$. 加齢に伴い，産生される抗体は量 的に減少するだけでなく，質的にも親和性が低くなる，す なわち抗原との結合力が低下する ${ }^{32}$ 33). このように，加齢 により免疫機能が低下した身体状況において, 抗体の摂取 によるいわゆる受身免疫は, 免疫力を高める最屯確実な手 段であると思われる. 加齢により有害菌が増加し, ビフィ ズス菌などの有用菌が減少する ${ }^{13)}$ が，これに対して，未公 表結果ではあるが, ウシ抗体の摂取が便臭の減少, 腸内細 菌叢の改善に寄与するとの治験結果を得ている.

また，関節リウマチなどの自己免疫疾患の発症には微生 物環境が重要であることが報告されている ${ }^{34)}{ }^{36)}$. TNF，イ ンターロイキン-6 をはじめとする炎症性サイトカインは, 消化管から移行した細菌毒素によって活性化された免疫細 胞により産生される可能性がある. 本研究で, WPC 中に は細菌毒素を中和する抗体が存在することが明らかとなっ た. WPC の抗細菌毒素抗体が関節リウマチの治療に寄与 するという仮説による予備的な治験において，WPC は患 者の半数に有効であった (片山耕, 他 ミルク抗体の関節リ ウマチへの治療効果, 第 52 回日本リウマチ学会総会・学術 集会プログラム・抄録集, P 2-178, p. 351, 北海道 (2008)). 腸内細菌叢の改善が健康維持・増進に寄与することが明 
らかとなった今日，WPC 中の抗体は多方面への適用が期 待できる37).

$$
\text { 要 約 }
$$

ウシ生乳に含まれる抗体の有効利用を目的として，乳清 （ホエー）のタンパク部分を濃縮して得られた乳清タンパ ク濃縮物（WPC）に含まれる抗体量およびその特異性を調 ベた。

ヒト由来病原菌 33 種とエンドトキシン，エンテロトキ シン, lipid A など $5 つ の$ 細菌毒素を指標に抗体の検出と 定量を試みた。その結果，33 種の細菌と 5 種の細菌毒素全 てに対する抗体が検出された。このことは，今回の抗体検 索に用いなかった細菌や毒素に対する抗体も含まれる可能 性を示唆した。また, 細菌菌体による吸収試験から, WPC には複数の細菌に対して広範に反応し得る抗体が含まれる ことが明らかとなった。

以上，ウシの乳に含まれる抗体を利用するに当たり，ウ シに病原微生物による免疫を施さなくても, WPC 中にはヒ 卜病原菌に対する抗体が含まれることを示した。しかし， WPC 中の総 IgG 含有量は必ずしも個々のヒト病原菌に対 する抗体量とは相関しなかったことから，ヒトの健康への 寄与を意図してWPC を使用するためには，目的とする細 菌や毒素に対する個別の抗体量を把握することが重要と考 えられた。

ウシ免疫抗体の作成に際しご協力いただきました鈴木秀 歌様（現 静岡県西部家畜保健衛生所）, 加藤雅通様（現 静岡県農林業局畜産振興室）に感謝申し上げます。

\section{文献}

1) Korhonen, H., Marnila, P. and Gill, H.S., Bovine milk antibodies for health., Br. J. Nutr., 84 (Suppl 1), 135-146 (2000).

2) Kushnareva, M.V., Keshishian, E.S. and Soboleva, S.V., The efficacy of using an immune lactoglobulin preparation for correcting intestinal dysbacteriosis in newborn infants, Zh. Mikrobiol. Epidemiol. Immunobiol., 2, 101-104 (1995).

3) Stephan, W., Dichtelmüller, H. and Lissner, R., Antibodies from colostrum in oral immunotherapy., J. Clin. Chem. Clin. Biochem., 28, 19-23 (1990).

4) Florén, C.H., Chinenye, S., Elfstrand, L., Hagman, C. and Ihse, I., ColoPlus, a new product based on bovine colostrum, alleviates HIV-associated diarrhoea., Scand. J. Gastroenterol., 41, 682-686 (2006).

5) Rump, J.A., Arndt, R., Arnold, A., Bendick, C., Dichtelmüller, H., Franke, M., Helm, E.B., Jäger, H., Kampmann, B., Kolb, P., Kreuz, W., Lissner, R., Meigel, W., Ostendorf, P., Peter, H.H., Plettenberg, A., Schedel, I., Stellbrink, H.W. and Stephan, W., Treatment of diarrhoea in human immunodeficiency virus-infected patients with immunoglobulins from bovine colostrum., Clin. Invest., 70, 588-594 (1992).
6）丸山 務，環境の変化之人畜共通感染症，臨床獣医，15，1342 (1997).

7) Murinda, S.E., Nguyen, L.T., Landers, T.L., Draughon, F. A., Mathew, A.G., Hogan, J.S., Smith, K.L., Hancock, D.D. and Oliver, S.P., Comparison of Escherichia coli isolates from humans, food, and farm and companion animals for presence of Shiga toxin-producing E. coli virulence markers., Foodborne Pathog Dis., 1, 178-184 (2004).

8) Dmitriev, A., Tkáciková, L., Suvorov, A., Kantíková, M. Mikula, I. and Totolyan, A., Comparative genetic study of B streptococcal strains of human and bovine origin., Folia Microbiol (Praha)., 44, 449-453 (1999).

9) Han, M.G., Wang, Q., Smiley, J.R., Chang, K.O. and Saif, L.J., Self-assembly of the recombinant capsid protein of a bovine norovirus (BoNV) into virus-like particles and evaluation of cross-reactivity of BoNV with human noroviruses., J. Clin. Microbiol., 43, 778-785 (2005).

10) Batten, C.A., Clarke, I.N., Kempster, S.L., Oliver, S.L., Bridger, J.C. and Lambden, P.R., Characterization of a cross-reactive linear epitope in human genogroup III and bovine genogroup III norovirus capsid proteins., Virology, 356, 179-187 (2006).

11) Bojsen, A., Buesa, J., Monotava, R., Kvistgaard, A.S., Kongsbak, M.B., Petersen, T.E., Heegaard, C.W. and Rasmussen, J.T., Inhibitory activities of bovine macromolecular whey proteins on rotavirus infections in vitro and in vivo., J. Dairy Sci., 90, 66-74 (2007).

12) Bölke, E., Jehle, P.M., Hausmann,F., Däubler, A., Wiedeck, H., Steinbach, G., Storck, M. and Orth, K., Preoperative oral application of immunoglobulin-enriched colostrum milk and mediator response during abdominal surgery., Shock, 17, 9-12 (2002).

13）光岡知足, 老化之腸内細菌, 老年消化器病，13，85-90 (2001).

14）日本救急医学会医学用語解説集, http : / / w ww.jaam.jp/ $\mathrm{html} / \mathrm{report} /$ dictionary/word/1120.htm

15) Velin, A.K., Ericson, A.C., Braaf, Y., Wallon, C. and Söderholm, J.D., Increased antigen and bacterial uptake in follicle associated epithelium induced by chronic psychological stress in rats., Gut, 53, 494-500 (2004).

16) Inutsuka, S., Takesue, F., Yasuda, M., Honda, M., Nagahama, S., Kusumoto, H., Nozoe, T. and Korenaga, D., Assessment of the intestinal permeability following postoperative chemotherapy for human malignant disease., Eur. Surg. Res., 32, 22-25 (2003).

17) Mizoguchi, H., Ogawa, Y., Kanatsu, K., Tanaka, A., Kato, S. and Takeuchi, K., Protective effect of rebamipide on indomethacin-induced intestinal damage in rats., $J$. Gastroenterol. Hepatol., 16, 1112-1119 (2001).

18) Butlur, J.E., Bovine immunoglobulins: A review, J. Dairy Sci., 52, 1895-1909 (1969).

19) Fox, J. and Hechemy, K., Coupling of Escherichia coli lipopolysaccharide to epoxy-activated Sepharose 6B., Infect. Immun., 20, 867-868 (1978).

20) McMartin. S., Godden, S., Metzger, L., Feirtag, J., Bey, R. Stabel, J., Goyal, S., Fetrow, J., Wells, S. and ChesterJohnes, H., Heat treatment of bovine colostrums. 1 : Effect of temperature on viscosity and immnunoglobulin G level., J. Daily Sci., 89, 2110-2118 (2006).

21) Johns, M.A., Bruins, S.C. and McCabe, W.R., Immunization with R mutants of Salmonella minnesota. II. Serological response to lipid A and the lipopolysaccharide of Re mutants., Infect. Immun., 17, 9-15 (1977).

22) Tyler, J. and Spears, H., Cullor, J., Smith, W., Nelson, R. 
and Martin, J., Antigenic homology among gramnegative organisms isolated from cattle with clinical mastitis., J. Dairy Sci., 74, 1235-1242 (1991).

23) Mutharia, L.M., Crockford, G., Bogard, W.C. Jr. and Hancock, RE., Monoclonal antibodies specific for Escherichia coli J5 lipopolysaccharide : Cross-reaction with other gram-negative bacterial species., Infect. Immun., 45, 631-636 (1984).

24) Kunin, C.M., Separation, characterization, and biological significance of a common antigen in enterobacteriaceae. J. Exp. Med., 118, 565-586 (1963).

25) Young, D.A., Dobson, P. and Karakawa, W.W., Immunological specificity of natural opsonins and their role in the cross-reactivity between Staphylococcus aureus Mardi and Escherichia coli 101. Infect. Immun., 25, 954959 (1979).

26) Schmucker, D.L., Owen, R.L., Outenreath, R. and Thoreux, K., Basis for the age-related decline in intestinal mucosal immunity., Clin. Dev. Immunol., 10, 167-172 (2003).

27) Zheng, K.C. and Ariizumi, M., Modulations of immune functions and oxidative status induced by noise stress., J. Occup. Health, 49, 32-38 (2007).

28) Beilin, B., Shavit, Y., Trabekin, E., Mordashev, B., Mayburd, E., Zeidel, A. and Bessler, H., The effects of postoperative pain management on immune response to surgery., Anesth. Analg., 97, 822-827 (2003).

29) Stein, M., Keller, S.E. and Schleifer, S.J., Stress and immunomodulation: the role of depression and meuroendocrine function., J. Immunol., 135, 827s-837s (1985).

30) Shavit, Y., Terman, G.W., Martin, F.C., Lewis, J.W., Liebeskind, J.C. and Gale, R.P., Stress, opioid peptides, the immune system, and cancer., J. Immunol., 135, 834s837s (1985).

31) Thoreux, K., Schmucker, D.L., Kefir milk enhances intestinal immunity in young but not old rats., J. Nutr., 131, 807-812 (2001).

32) Lemaoult, J., Szabo, P. and Weksler, M.E., Effect of age on humoral immunity, selection of the B-cell repertoire and B-cell development., Immunol. Rev., 160, 115-126 (1997).

33) Howard, W.A., Gibson, K.L. and Dunn-Walters, D.K., Antibody quality in old age., Rejuvenation Res., 9, 117125 (2006).

34) Penhale, W.J. and Young, P.R., The influence of the normal microbial flora on the susceptibility of rats to experimental autoimmune thyroiditis., Clin. Exp. Immunol., 72, 288-292 (1988).

35) Murakami, M., Tsubata, T., Shinkura. R., Nisitani, S., Okamoto, M., Yoshioka, H., Usui, T., Miyawaki, S. and Honjo, T., Oral administration of lipopolysaccharides activates B-1 cells in the peritoneal cavity and lamina propria of the gut and induces autoimmune symptoms in an autoantibody transgenic mouse., J. Exp. Med., 180, 111-121 (1994).

36) Murakami, M., Nakajima, K., Yamazaki, K., Muraguchi, T., Serikawa, T. and Honjo, T., Effects of breeding environments on generation and activation of autoreactive B-1 cells in anti-red blood cell autoantibody transgenic mice., J. Exp. Med., 185, 791-794 (1997).

37）アサマ化成株式会社, 乳清タンパク食品, 特開 2006-149371, 2006. 6.15

(平成 20 年 9 月 29 日受付, 平成 21 年 6 月 4 日受理) 